$+$

$\mathbf{z}$

\title{
DEFLUORIDATION STUDY FOR BOISE GEOTHERMAL WATER
}

Lester Rigdon

This is an informal report intended primarily for internal or limited external distribution. The opinions and conctusions stated are those of the author and may or may not be those of the Laboratory.

Work performed under the auspices of the U.S. Department of Energy by the Lawrence Livermore Laboratory under Contract W-7405-Eng-48. 


\section{DISCLAIMER}

This report was prepared as an account of work sponsored by an agency of the United States Government. Neither the United States Government nor any agency Thereof, nor any of their employees, makes any warranty, express or implied, or assumes any legal liability or responsibility for the accuracy, completeness, or usefulness of any information, apparatus, product, or process disclosed, or represents that its use would not infringe privately owned rights. Reference herein to any specific commercial product, process, or service by trade name, trademark, manufacturer, or otherwise does not necessarily constitute or imply its endorsement, recommendation, or favoring by the United States Government or any agency thereof. The views and opinions of authors expressed herein do not necessarily state or reflect those of the United States Government or any agency thereof. 


\section{DISCLAIMER}

Portions of this document may be illegible in electronic image products. Images are produced from the best available original document. 


\section{CONTENTS}

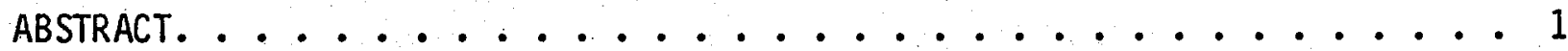

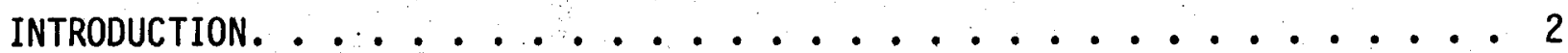

THE BOISE GEOTHERMAL PROJECT. ............... 2

QUALITY OF THE BOISE GEOTHERMAL WATER ............ 2

DISPOSAL OF SPENT GEOTHERMAL WATER. ...................... 4

TECHNIQUES FOR REMOVING FLUORIDES FROM WATER. .......... 5

REVERSE OSMOSIS ................... 5

Definition and Description of Reverse Osmosis Process. . ... 5

Reverse Osmosis Plant Performance and Cost Experience. . . . . 6

ELECTRODIALYSIS .................... 7

Definition and Description of the Electrodialysis Process. . . . 7

Electrodialysis Plant Performance and Cost Experience. . . . 8

PRECIPITATION AND COAGULATION . ............. 8

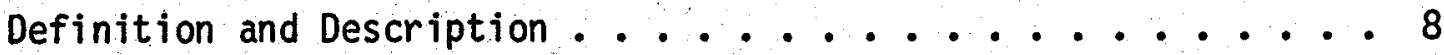
Precipitation and Coagulation Plant

Performance and Cost Experience............ 9

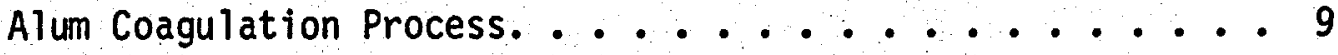

Magnesium-Lime Softening. ........... . . 10

other Precipitation Methods . . . . . . . . . 10 


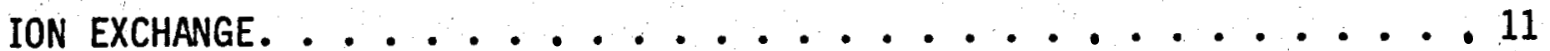

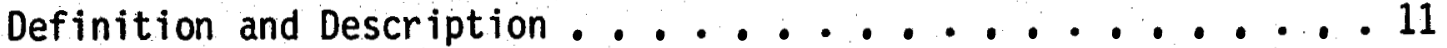

Activated Alumina .................. 12

Synthetic Resin Ion Exchangers. .......... 15

Ion Exchange Plant Performance and Cost Experience . . . . 15

Synthetic Resin Ion Exchange Water Treatment Plants .... 15

Alumina Ion Exchange for Fluoride Removal. ........ 15

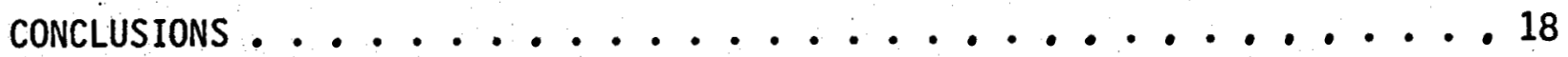

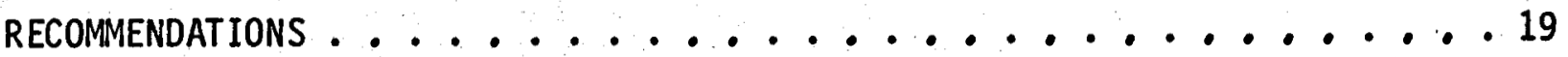

DEFLUORIDATE BY ION-EXCHANGE PROCESS. . . . . . . . . . 19

Determine the Best Ion-Exchange Medium .......... 19

Determine whether Batch or Continuous Media. . . . . . . 19

Determine Most Suitable Procedure. . . . . . . . . . 19

Determine the Effects of $\mathrm{pH}$ Control. ........... 19

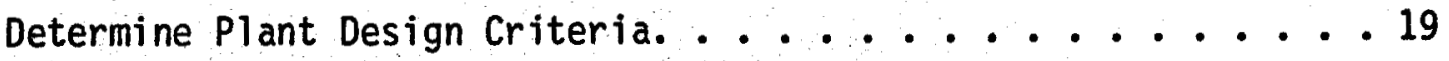

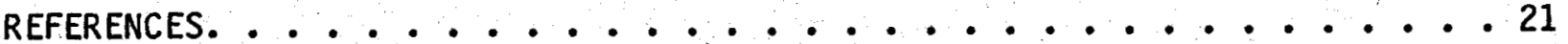


DEFLUORIDATION STUDY FOR BOISE GEOTHERMAL WATER

Lester Rigdon

Lawrence Livermore Laboratory

University of California

Livermore, CA 94550

ABSTRACT

Methods of removing fluorides from water are reviewed and recommendations are made for treating geothermal water used by the Boise Geothermal Project, Boise, Idaho. The Boise geothermal water except for its high fluoride content would be high quality, suitable for primary drinking water. Fluoride ranges from about 15 to $25 \mathrm{mg} / 1$ in water from various wells in the Boise region where the Project $p l a n s$ to obtain hot water. Four techniques for removing fluorides from water have been studied extensively during the past 15 years or so. Electrodialys is and reverse osmosis are useful in reducing total dissolved solids from brackish water, but are nonspecific and are too expensive for treatment of the Boise geothermal water. Selective precipitation is a widely used technique for treating water, but would also prove expensive for the Boise geothermal water because of the relatively high solubility of fluoride salts and consequently high concentration (and cost) of precipitants required to reduce the fluorides to an acceptable level. Ion-exchange separation using activated alumina as the exchange medium appears to be the most promising technique and we recommend that some laboratory and pilot studies be conducted to establish suitability and operating boundaries. 
THE BOISE GEOTHERMAL PROJECT

\section{INTRODUCTION}

A joint geothermal energy project between the City of Boise, Idaho and the Boise Warm Springs Water District is being sponsored by the Department of Energy. ${ }^{1}$ The primary purpose of the project is to take hot water from the ground and use it for space heating of homes, offices, and public buildings. Secondary uses where in residual thermal value will be extracted from the water for heating animal cages, irrigating farmland, and supplying warm water fisheries have been proposed.

Recent discussions of the geology of the Boise area and the geothermal resource can be found in the Boise Geothermal Energy Systems PIan, ${ }^{1}$ and the report on Geothermal Potential of the West Boise Area. ${ }^{2}$ The Boise Geothermal resource is associated with the Foothills Fault which trends along the edge of the city on a northwest-southwest line. It is believed that the Foothills Fault is a zone of fractures perhaps several hundred yards wide extending deep enough into the earth's crust to allow vertical migration of water to a great depth where it is heated and then returned to the near surface.

It is anticipated that initially up to 4,000 gallons per minute of water having a temperature of $170^{\circ} \mathrm{F}$ will be drawn from the Foothills Fault fracture zone near downtown Boise. The hot water will be drawn from wells 1,000 to 1,500 feet deep on a demand basis as needed for space heating. There will be wide and frequent fluctations of the geothermal water flow with changes in the seasons and local weather. The annual flow is estimated to be 260 million gallons or about 800 acre feet.

QUALITY OF THE BOISE GEOTHERMAL WATER

The geothermal water in the Boise area is very high quality and several analyses indicate that only fluoride exceeds safe drinking water levels established in the National Interim Primary Drinking Water Regulations. ${ }^{3}$ The fluoride concentration in the geothermal water ranges from about 15 to 25 $\mathrm{mg} / 1$ while the water from the surface aquifer and the Boise River is reported 
to average about $0.5 \mathrm{mg} / 1$. Total dissolved solids (TDS) concentrations range between 200 and $300 \mathrm{mg} / 1$. Bicarbonate, fluoride, silica, sodium, and sulfate account for more than $90 \%$ of the TDS. Boron, calcium, chloride, nitrate, phosphate and other innocous species have also been reported from trace levels to a few $\mathrm{mg} / \mathrm{ml}$. Typical analyses of raw water from one Boise geothermal well and three public water supplies which are being defluoridated are shown in Table 1. Boise geothermal well water samples were taken May 16, 1980 and analyzed on site immediately, and again at Lawrence Livermore National Laboratory, May 19-30, 1980.

Table 1. Water analysis from three defluoridation plants and one Boise, Idaho geothermal well.

\begin{tabular}{|c|c|c|c|c|}
\hline \multirow[b]{2}{*}{$\begin{array}{l}\text { Parameter, in } \\
\text { Mg/I Except pH }\end{array}$} & \multicolumn{4}{|c|}{ LOCATION } \\
\hline & $\begin{array}{l}\text { Desert } \\
\text { Center, CA. }\end{array}$ & Vail, Ariz. & $\begin{array}{l}\text { Gila } \\
\text { Bend, Ariz. }\end{array}$ & $\begin{array}{l}\text { Boise } \\
\text { Geothermal } \\
\text { Well }\end{array}$ \\
\hline $\mathrm{Ca}$ & 11 & 51 & 31 & 0.5 \\
\hline Mg & 0.5 & 5.8 & 1 & 0.3 \\
\hline $\mathrm{Na}$ & 58 & 151 & 396 & 84 \\
\hline $\mathrm{SO}_{4}$ & 40 & 261 & 160 & 20 \\
\hline ci & 67 & 22 & 540 & 12 \\
\hline Hardness as $\mathrm{CaCO}_{3}$ & 30 & 152 & 78 & 2 \\
\hline Alkalinity as $\mathrm{CaCO}_{3}$ & 77 & 171 & 30 & 120 \\
\hline $\mathrm{HCO}_{3}^{-}$ & - & - & - & 145 \\
\hline $\mathrm{SiO}_{2}$ & 22 & 55 & 21 & 78 \\
\hline$F^{-}$ & 7.5 & 4.5 & 6.0 & 18.4 \\
\hline TDS & 409 & 605 & 1121 & 285 \\
\hline pH & 7.9 & 7.5 & 8.3 & 9.3 \\
\hline
\end{tabular}


Fluoride is the only substance found in the geothermal water which constitutes a pollution disposal problem. The maximum permissible concentration range of fluoride for drinking water is 1.4 to $2.4 \mathrm{mg} / 1$, and neither the Boise River or the surface aquifer can receive the maximum flows expected of the geothermal project without danger of exceeding the permissible fluoride levels. Furthermore, if a zero degradation policy is followed, no untreated geothermal water could be discharged to the Boise River or surface aquifer. Thus development of the geothermal resource on a large scale brings with it the problem of disposing of large quantities of spent geothermal water in an environmentally acceptable manner.

DISPOSAL OF SPENT GEOTHERMAL WATER

The following disposal alternatives for the spent geothermal water have been discussed previously: ${ }^{1}$

- Injection

- Discharge into the Boise river

- Disposal into sanitary sewers

- Disposal into an agricultural canal

- Disposal into leach/evaporation pond

- Reuse

Only injection or leach/evaporation pond disposal appear to be environmentally acceptable. However, if the fluoride concentration could be reduced, then other options could be adopted. For example, it could be blended with the Boise fresh water supply to yield 0.7 to $1.2 \mathrm{mg} / 1$ fluoride, which is the recommended concentration range for drinking water. ${ }^{3}$

Therefore, it is desirable to find an efficient and economical method for removing fluorides from the spent geothermal water so that its value for reuse can be enhanced and its ultimate disposal will not create an environmental problem. Accordingly, the purpose of this document is to present a discussion of various techniques and processes which can be used to remove fluorides from water and to recommend studies of the Boise geothermal water which seem most likely to succeed in reducing the fluoride concentration to an acceptable level. 
TECHNIQUES FOR REMOVING FLUORIDES FROM WATER

Four techniques which can be used to remove or reduce the concentration of fluoride in water have been extensively studied during the past 15 years or so. Electrodialysis and reverse osmosis are similar in that they use semipermeable membranes to reduce the total dissolved solids in water and are non-specific. Precipitation is a widely used technique for treating various kinds of waste water. It can be used for removing specific constituents or classes of contaminents but is not suitable for reducing fluoride to the desired 1-2 $\mathrm{mg} / 1$. Ion-exchange processes appear to be the most economical technique for reducing the fluoride content of the Boise geothermal water to an acceptable level. Nonetheless, all four techniques will be described and discussed briefly in the following sections so that more definitive judgments of the four techniques can be made.

\section{REVERSE OSMOSIS}

Definition and Description of the Reverse Osmosis Process

Osmosis is a natural phenomenon which occurs when two solutions of different concentrations are separated by a semipermeable membrane. Water tends to flow from the more dilute side to the more concentrated side until the concentration of the solute on both sides is equal. The ideal membrane permits passage of water molecules, but prevents passage of ions such as sodium, chloride, fluoride, etc. For example, if a solution of sodium chloride in water is separated from pure water by a semipermeable membrane, water will pass through the membrane in both directions, but it will pass more rapidiy in the direction of the salt solution until the pressure on each side is equal. The force that causes the water to flow to the solute side is the osmotic pressure, and depends on the concentration of the salt solution. 4

By exertion of pressure on the salt solution, the osmosis process can be reversed. When thelpressure on the salt solution is greater than the osmotic pressure, water molecules diffuse through the membrane in the direction opposite to normal osmotic flow, hence the name for the process, reverse osmosis. 
Reverse osmosis is a non-selective process which reduces the concentration of all dissolved solids, and has been reported to remove up to 90-95 percent of all dissolved minerals from water, 95-97 percent of all dissolved organics and more than 98 percent of biological and collodial matter. ${ }^{5}$. Rejection of a species is directly related to its size and charge. ${ }^{6}$ Therefore, the small monovalent fluoride ion $\left(F^{-}\right)$would not be as effectively removed by reverse osmosis as the larger monovalent bicarbonate and divalent sulfate ions which also are major dissolved minerals in the Boise geothermal water.

Reverse Osmosis Plant Performance and Cost Experience.

The percentage of dissolved matter removed from water by reverse osmosis depends upon a number of variables, including the amount and kinds of dissolved solids in the feed water, the number of membrane stages, the applied pressure, and the percent conversion (ratio of permeate to feed water) chosen.

The volume and concentration of waste for disposal are determined by the percent conversion chosen. For example, a plant which removed $90 \%$ of the TDS with $80 \%$ conversion from $1 \mathrm{mgd}$ of feed water containing $300 \mathrm{ppm}$ TDS would produce $800,000 \mathrm{gpd}$ of product water containing $30 \mathrm{ppm}$ TDS and 200,000 gpd of waste for disposal containing 1380 ppm TDS.

The performance and cost experience of seven commercial reverse osmosis desalting plants have been reviewed by Hornburg, et al. ${ }^{7}$ The plants, installed from 1970 to 1972, were designed to treat 2,500 to $930,000 \mathrm{gpd}$ of water containing from 1500 to $7000 \mathrm{ppm}$ TDS. The cost per 1000 gal. of potable water for the plants surveyed ranged from $\$ 0.52$ to $\$ 1.25$ during 1970-1975. Moore has also presented extensive data for the Greenfield, Iowa reverse osmosis plant operation from January 1 to April 30, 1972. ${ }^{8}$ This plant was designed to produce $150,000 \mathrm{gpd}$ of potable water containing $500 \mathrm{ppm}$ TDS from feed water containing $2250 \mathrm{ppm}$ TDS. It was operated at $54.3 \%$ load factor and cost $20.5 \$ / 1000 \mathrm{gal}$ of potable water for operating costs excluding labor. The cost was $76.7 \$ / 1000$ gal at a $54.3 \%$ load factor when labor and amortized capital costs were included.

Shields ${ }^{5}$ described the principles and some of the engineering arrangements for reverse osmosis plants. He presented some data on two commercial reverse osmosis plants and compared the costs and benefits of 
upgrading the quality of municipal water by reverse osmosis with conventional water treatment and desalting costs. He estimated that (in 1972 dollars) a large (about $5 \mathrm{mgd}$ ) reverse osmosis plant would cost $25 \$$ per gallon per day to build and $25 \$ / 1000$ gal. to operate.

\section{ELECTRODIALYSIS}

\section{Definition and Description of the Electrodialysis Process}

Dialysis is a technique used to separate substances in solution by means of a semipermeable membrane through which the smaller molecules and ions diffuse readily while the larger molecules and ions diffuse very slowly or not at all. The process is accelerated in electrodialysis by passing a current through an electrolytic cell that is divided into three separate sections by two different ion-selective membranes. The section on one side contains a cathode, which attracts the positively charged ions through a membrane permeable to positive ions. The section at the other side of the cell contains an anode which attracts negative ions through a membrane permeable to negative ions. The middle section between the membranes contains water of reduced salinity or ionized minerals.

Electrodialysis plants use membrane stacks made up of many alternating cation and anion membranes each separated by a plastic spacer. The spacers (about $0.04 \mathrm{in.}$ thick) contain the water streams within the stack and direct the flow of water through a tortuous path across the exposed face of the membranes. End plates and tie rods complete the stack assembly. Usually 10 to 20 seconds are required for the feed water to pass between the membranes of a single stack or stage, minerals are removed from the feed water during that time.

Like reverse osmosis, electrodialysis is a non-specific process which is most useful in demineralizing brackish water to potable water, and is being used to demineralize waste water in some instances. Unlike reverse osmosis which allows water molecules to pass through a semipermeable membrane, electrodialysis forces dissolved minerals and ionized substances through a semipermeable membrane. Thus, ions are removed from the water, but little if any dissolved organics, biological or colloidal matter are removed by electrodialysis. 


\section{Electrodialysis Plant Performance and Cost Experience}

The percentage of dissolved matter removed from water by electrodialysis also depends upon a number of variables, including water temperature, amount and kind of dissolved solids in the feed water, the flow rate, stack design and number of stages. Typically, 25 to 60 percent is removed per stage, 4 and commercial plants employ one to six stages. The flow rate of blowdown water which flows through the section of the electrolytic cell that receives the minerals is' a design and operating variable, and ranges from 9 to 50

percent of the feed. ${ }^{7}$ This water, like that in reverse osmosis, is a waste water high in TDS which must be disposed of in an environmentally acceptable manner.

The performance and cost experience of four commercial electrodialysis plants were reviewed by. Hornburg et al. ${ }^{7}$ along with seven reverse osmosis plants, previously discussed. The electrodialysis plants were also installed during the period 1970 to 1973 and designed to treat 70,000 gpd to $2.0 \mathrm{mgd}$. Costs ranged from $51.8 \$$ to $\$ 1.24 / 1000$ gal of potable water including capital amortization. Scheffer has also presented extensive data for the Buckeye, Arizona, electrodialysis plant for the period 1963 to $1970 .^{9}$ That plant was designed to produce 650,000 gpd of potable water containing less than $500 \mathrm{ppm}$ TDS from we 11 water containing 1500 to $2500 \mathrm{ppm}$ TDS. Operating costs averaged over the eight year period were $71.4 \$ / 1000$ gal. with an average load factor of $30 \%$, and were estimated to be $40.3 \$ / 1000$ if the plant were operated at $90 \%$ of capacity. Capital amortization and the cost of blowdown water added $20 \$$ to $55 \$$ more per 1000 gal. The cost of larger electrodialysis plants should be about the same as those for large reverse osmosis plants, discussed earlier.

PRECIPITATION AND COAGULATION

\section{Definition and Description}

Both precipitation and coagulation techniques for treating water cause some dissolved constituent(s) to form a solid which can be removed by settling or filtration. Coagulation yields a flocculent precipitate which often 
co-precipitates or absorbs other species that do not form the initial precipitate; whereas precipitation usually refers to the production of a more dense solid as the result of a specific chemical reaction. A chemical must be added to the water to cause a precipitate or coagulum to form. Often the $\mathrm{pH}$ of the water must be adjusted after the precipitate is removed, thereby increasing the TDS and the cost. For example, lime softening of water (the addition of $\mathrm{CaO}$ ) causes an increase of the $\mathrm{pH}$ (to about $\mathrm{pH} 11$ ) so that it must be recarbonized (treated with $\mathrm{CO}_{2}$ ) to neutralize it before use or discharge.

\section{Precipitation and Coagulation Plant Performance and Cost Experience}

Precipitation and coagulation are widely used methods of treating both fresh and waste water and can be used to remove a variety of substances from water, including most heavy metals, magnesium, some phosphates and fluorides.

Alum Coagulation Process. A study of the variables of the alum coagulation process was conducted by Culp and Stoltenberg ${ }^{10}$ using highly mineralized water at La Crosse, Kansas. They report that "the fluoride removal is directly dependent on the efficiency of the alum flocculation, which is in turn related to $\mathrm{pH} . "$ They found the optimum $\mathrm{pH}$ range to be from 6.5 to 7.5 and the residual aluminum to be less than $0.25 \mathrm{ppm}$ in that $\mathrm{pH}$ range. Lime was used to stabilize the $\mathrm{pH}$, and it was estimated that $315 \mathrm{ppm}$ of alum and $20 \mathrm{ppm}$ of lime would reduce the fluoride concentration from 3.6 to $1.0 \mathrm{ppm}$, under optimum conditions. Costs in 1958 values for 1 ime and alum only were estimated to be $8 \$$ per 1000 gallons of water. Unfortunately the authors did not study the removal of higher fluoride concentrations. The Al(III) concentration would be $28.5 \mathrm{ppm}$ when $315 \mathrm{ppm}$ of alum $-\mathrm{Al}_{2}\left(\mathrm{SO}_{4}\right)_{3} \cdot 14 \mathrm{H}_{2} \mathrm{O}-$ is used to treat the water.

Clarke and Wilson studied the removal of fluoride from water by adsorption onto colloidal aluminum hydroxide. 11 The colloidal suspension was removed by foaming with sodium lauryl sulfate. They report that fluoride was reduced from 19.7 to $4 \mathrm{ppm}$ by $40 \mathrm{ppm}$ of Al(III) and $40 \mathrm{ppm}$ of sodium lauryl sulfate when the $\mathrm{pH}$ was maintained between 7.3 and 7.9. The $A 1 / F$ removal ratio (ppm of Al added/ppm.F removed) was 2.54 under the above conditions, which the authors considered to be optimum. Their studies show that a higher percentage of fluoride can be removed by increasing the Al/F ratio. 
Sor $g^{6}$ reviewed alum coagulation techniques and reports that "results among the various researchers varied considerably, probably because of variation in such test conditions as the raw water, mixing and $\mathrm{pH}$. All results, however, were consistent in that large doses of alum were required to remove small amounts of fluoride."

Magnesium-Lime Softening. Fluoride can be removed by co-precipitation with and adsorption by magnesium hydroxide in the lime softening process. Scott et al. ${ }^{12}$ determined that the amount of fluoride removed depends upon the amount of magnesium removed during the lime softening process, and developed the following formula showing the relationship between fluoride and magnesium removal:

$$
F_{r}=F_{j}-\left(0.07 F_{j} \sqrt{M g}\right)
$$

where $F_{r}$ is the residual fluoride concentration, $F_{i}$ the initial fluoride concentration, and $\mathrm{Mg}$ the amount of $\mathrm{Mg}$ removed. A reduction from 20 to $1 \mathrm{ppm}$ of fluoride would require precipitation of $184 \mathrm{ppm}$ of $\mathrm{Mg}$ according to this formula. Culp and Stoltenberg ${ }^{10}$ found good agreement between their experimental data and predictions made using the formula. However, magnesium can be completely precipitated only at $\mathrm{pH} 11$ or higher. Therefore, excessive amounts of magnesium and/or lime and recarbonization would be required for the Boise geothermal water. Sorg ${ }^{6}$ believes that the method is useful only for low-fluoride-high-magnesium water requiring softening.

Other Precipitation Methods. Calcium fluoride $\left(\mathrm{CaF}_{2}\right)$ is only slightly soluble, and the fluoride concentration of water can be reduced to about $8 \mathrm{ppm}$ by adding a large excess of lime. This process is a useful preliminary treatment for waste water from industrial processes containing up to several hundred ppm of fluoride, but is not satisfactory for the Boise geothermal water. It may be useful in disposing of the fluoride concentrate, however. Fluorides can also be precipitated as calcium fluorapatite, $\mathrm{Ca}_{5}\left(\mathrm{PO}_{4}\right)_{3} \mathrm{~F}$, and/or similar compounds. It is claimed that fluorides can be reduced to less than $1.0 \mathrm{mg} / 1$ by a commercially available treatment plant 
that uses phosphoric acid, calcium chloride and lime to precipitate fluorides as calcium fluorapatite. ${ }^{13}$ It is claimed that operating cost (1979) can be as low as $\$ 1.00$ per pound of fluoride removed. This seems optimistic because $\mathrm{Ca}_{5}\left(\mathrm{PO}_{4}\right)_{3} \mathrm{~F}$ is only $3.77 \% \mathrm{~F}$, thus 26.52 pounds of sludge would be produced per pound of fluoride removed or 4,400 pounds per million gallons of water having $20 \mathrm{ppm}$ of fluoride. Additional treatment of the water with a polyelectrolyte and $\mathrm{pH}$ adjustment are required by the process as well as disposal of a large amount of sludge, which makes the process appear unattractive for treating the Boise geothermal water.

\section{ION EXCHANGE}

\section{Definition and Description}

Ion exchange is the reversible interchange that takes place between ions of like charge, and usually occurs between ions present on an insoluble solid (the ion exchanger) and ions present in a solution surrounding the solid. Ion exchangers permit only the exchange of either cations or anions; therefore, mixed beds or separate beds of anion and cation exchangers are required in processes where both cations and anions are exchanged.

The capacity of an ion exchanger is the amount of ionic charge per unit weight or volume (milliequivalent per gram or $M^{3}$ ). The capacity of an exchanger for a particular species in some specified environment is an important parameter and is also sometimes referred to as the capacity perhaps in weight to volume units, i.e. grams of fluoride per cubic feet. An ion exchanger must be regenerated, by some type of chemical treatment, or discarded after it is loaded to capacity with ions absorbed during the beneficial process.

Regeneration of ion exchangers is a major expense (in both labor and chemicals) in water treatment. Fixed bed regeneration procedures for fluoride exchangers generally consist of a backwash, caustic wash, caustic rinse, acid neutralization, and water rinse. 14 Regeneration in some ion exchange processes has also been accomplished through somewhat more complicated engineering systems using continuous or pulsed flow regeneration techniques. ${ }^{4}$ 
The ion exchange process occurs naturally in soils, minerals, etc., and is applied for various purposes. The discovery that natural Zeolite (hydrous silicates of aluminum and sodium) ion exchangers could be used to soften water led to the development of artificial aluminosilicates first, then later synthetic ion exchange resins were developed. Ion exchangers can be somewhat tailored to selectively absorb one species, but usually there is little specificity and an exchanger will absorb innocuous ions as well as the ions of interest. Consequently exchangers that absorb fluoride also absorb bicarbonate and many other anions.

A wide variety of synthetic ion exchange resins, broadly classed as strong acid, weak acid, strong base, and weak base are commercially available. However, to date, none have had sufficient specificity for fluoride to be used in any community water treatment plant solely for removing fluoride. Calcium apatite, bone and bone char, and tricalcium phosphate were among the first ion exchangers used to defluoridate fresh water supplies. 14,15 These materials as well as others tested for removal of fluoride in contact beds suffer one or more serious drawbacks: low capacities, difficult or expensive to regenerate, high initial cost, appreciable solubility, and lack of selectivity toward the fluoride ion. ${ }^{16}$ Activated alumina possesses many of the same drawbacks, but has the advantage of low solubility, relatively low cost, and selectivity for fluoride over several other anions.

The adsorption of some anions by alumina in order of decreasing preference is reported to be the following:

$$
\mathrm{OH}^{-}, \mathrm{PO}_{4}^{-3}, \mathrm{~F}^{-}, \mathrm{SO}_{3}^{-2}, \mathrm{CrO}_{4}^{-2} \mathrm{NO}_{2}, \mathrm{Cl}^{-}, \mathrm{NO}_{3}^{-}, \mathrm{MnO}_{4}^{-}, \mathrm{SO}_{4}^{-2} \text {. }
$$

whereas the preference for anions by synthetic strong base resins is reported to be as follows ${ }^{(6)}$ :

$$
\mathrm{I}^{-}, \mathrm{HSO}_{4}^{-}, \mathrm{NO}_{2}^{-}, \mathrm{Br}^{-}, \mathrm{Cl}^{-}, \mathrm{OH}^{-}, \mathrm{HCO}_{3}^{-}, \mathrm{H}_{2} \mathrm{PO}_{4}^{-}, \mathrm{F}^{-}
$$

Activated Alumina. A study of some factors affecting the fluoride capacity of alumina were reported by Savine $11 i$ and $B 1$ ack ${ }^{16}$ along with a review of several processes for activating and regenerating alumina. They found that alumina can be regenerated with alum rather than caustic, and that the capacity for fluoride increased with increasing dosage of alum up to 12 pounds of alum per cubic foot of alumina. They also found that bicarbonate is absorbed along with fluoride and reduces the fluoride capacity correspondingly, and that neither chloride or sulfate anions reduce the $-12-$ 
capacity for fluoride. They believed the absorption of fluoride by alumina to be an ion exchange process. It has recently been shown that the process fits the Langmiur isotherm absorption model. 17,18

The total absorptive capacity of 26 to 48 mesh alumina for fluoride was derived from a Langmiur isotherm plot of experimental data by Wu and Nitya ${ }^{17}$ who report $12 \mathrm{mg}$ ( 630 umoles) of fluoride per gram of alumina. However, absorption isotherms are equilibium tests and do not necessarily indicate actual performance in a flow system. Wu and Nitya also report that the optimum $\mathrm{pH}$ for adsorption of fluoride is 5 , and at $\mathrm{pH} 5$ the rate of absorption of fluoride from water is a function of the ratio of the initial fluoride concentration to the activated alumina dose.

Batch reactor tests were performed to study the effects of mesh size, $\mathrm{pH}$, fluoride concentration, and alkalinity on fluoride removal by Bishop and Sansoucy. 18 They also used continuous flow, fluidized-column studies to evaluate fluidization characteristics, fluoride removal characteristics, regeneration procedures, and the extent of deterioration of the alumina exchanger. They found a linear increase in fluoride capacity with fluoride concentration of the influent water; a linear decrease of fluoride capacity with increase in alkalinity, and predictably, an exponential decrease of fluoride capacity with increase in $\mathrm{pH}$ over the range studied ( $\mathrm{pH}$ 5.5-8.0). This data is in good agreement with Wu and Nitya's $s^{17}$ rate data.

Activated alumina preferentially absorbs fluoride, carbonate, and bicarbonate ions in the $\mathrm{pH}$ range of 5 to 10. The fluoride capacity increases with decreasing $\mathrm{pH}$ in that range because the carbonates are converted to bicarbonates which are then converted to un-ionized carbonic acid according to the following reactions:

$$
\begin{aligned}
& \mathrm{CO}_{3}^{-}+\mathrm{H}^{+} \rightarrow \mathrm{HCO}_{3}^{-} \\
& \mathrm{HCO}_{3}^{-}+\mathrm{H}^{+} \rightarrow \mathrm{H}_{2} \mathrm{CO}_{3}
\end{aligned}
$$

A titration curve, showing the change of $\mathrm{pH}$ vs the amount of sulfuric acid added to $200 \mathrm{ml}$ of water taken from the Boise east penitentiary geothermal we 11 on May 16, 1980 is shown in Figure 1.

Other studies, including some cost estimates, for the removal of fluorides and arsenic from potable water and fluoride from industrial waste waters have recently been sponsored by the U. S. Environmental Protection Agency. 19,20 All of these reports prove that fluoride can be removed from water by alumina adsorption in contact beds. 


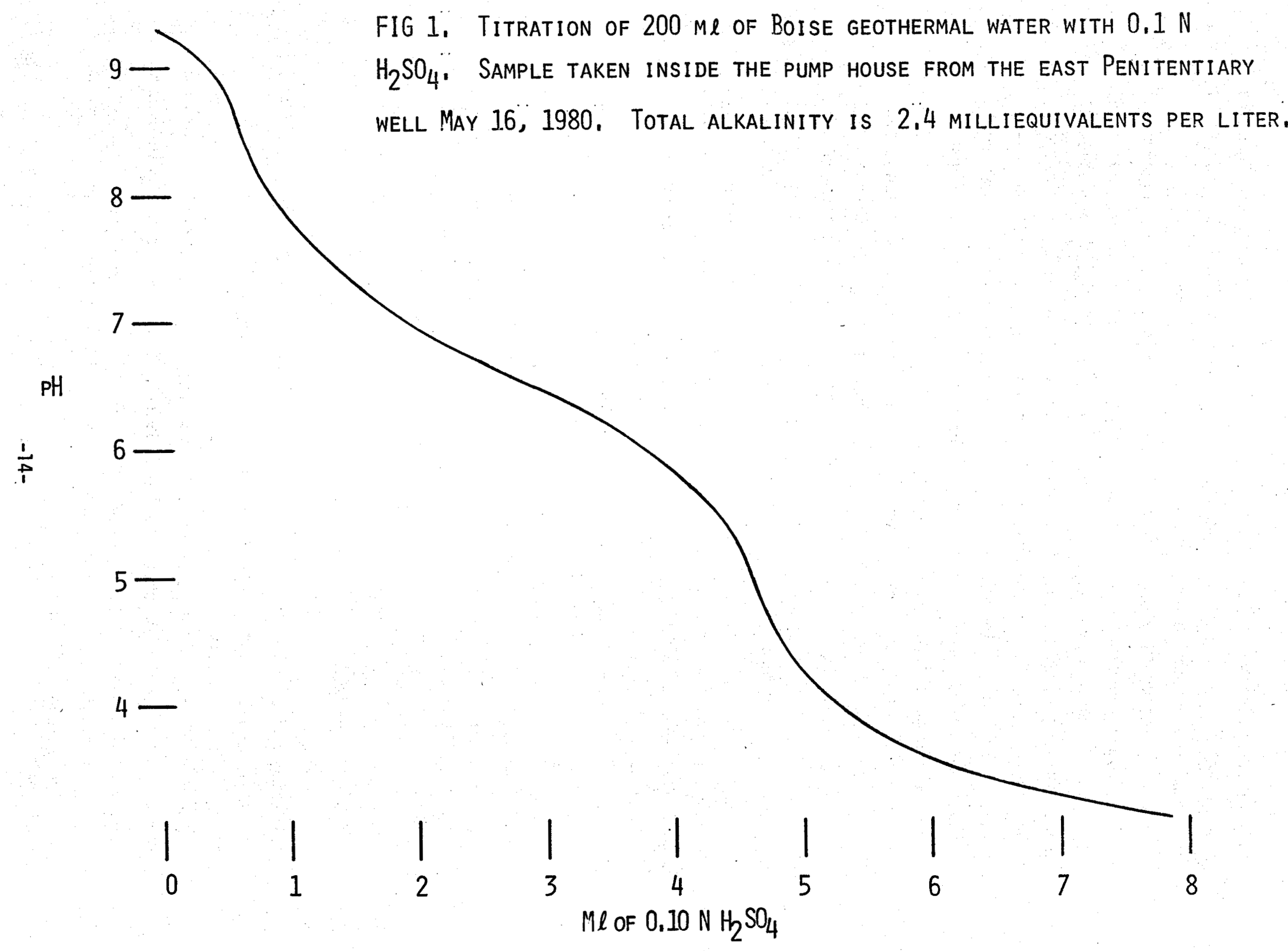


Synthetic Resin Ion Exchangers. The capacity of synthetic anion exchange resins for fluoride depends on the ratio of fluoride to total anions because practically all anions have a greater affinity for the resin than fluoride. Consequently, anion exchange resins usually are not considered for fluoride removal. In spite of this they should be considered for the Boise geothermal water because about $80 \%$ of the anions in the water are fluoride and bicarbonate, which are also absorbed by alumina. Synthetic ion exchange resins typically have capacities of 2-4 milliequivalents per gram whereas activated alumina has a capacity of about $0.6 \mathrm{meq}$ per gram, and is slow to reach equilibrium. 17

\section{Ion Exchange Plant Performance and Cost Experience}

Synthetic Resin Ion Exchange Water Treatment Plants. As indicated earlier, no ion exchange resin plants have been designed solely to remove fluoride from water. However, large scale water treatment plants have operated for years using cation, anion, and mixed exchangers to soften, demineralize, and remove nitrates from water. Several of these plants use a pulsed flow, continuously regenerating the exchanger $4,21,22$ rather than batch regeneration.

Experience with these plants indicates that synthetic resins stand up well and that continuous regeneration is an efficient process for large plants. For instance, the Alameda County Water District water softening plant at Fremont, $C A$, has four pulsed flow units with a capacity of $3.1 \mathrm{mgd}$ each. These units remove about $150 \mathrm{ppm}$ of hardness for about $5 \$ / 1000 \mathrm{gal}$. excluding manpower or capital costs.

\section{Alumina Ion Exchange for Fluoride Removal}

One of the earliest defluoridation plants to use activated alumina, at Bartlett, Texas, has been described by Maier. ${ }^{23}$ It was designed to reduce fluorides from $8 \mathrm{mg} / 1$ to $1.0 \mathrm{mg} / 1$ in water having about 500 and $400 \mathrm{ppm}$ of sulfate and alkalinity, respectively, with a capacity of $400 \mathrm{gpm}$. Costs for 
chemicals onily were $4.0 \$ / 1000$ gal. as compared to $5.3 \$ / 1000$ gal. for chemicals during the same period (1953) for the New Britton, S.D., plant which used bone char.

In 1978 Sorg $^{6}$ reported that only two large-scale activated alumina defluoridation plants were operating (at Desert Center, CA, and the X-9 Ranch near Tucson, Arizona) and that another was being constructed at Gila Bend, Arizona. He reports that no information on the design or operation of the plants has been published, but estimated the operating costs for reducing fluorides from 8 or $5 \mathrm{mg} / 1$ to $1.0 \mathrm{mg} / 1$ to be $15 \$-20 \$ / 1000 \mathrm{gal}$., on the basis of visits to the plants. These estimates are in agreement with Frankel's estimates of the Desert Center and Bartlett plants which he visited in $1976 .^{20}$ He also gave fairly detailed descriptions of those two plants.

More recently, Rubel and Woosley have published some data and operating costs for the Rincon Water Co. plant at Vail, Arizona, the Desert Center plant, and the Gila Bend plant. ${ }^{24}$ They report 1978 operating costs to be $10.4,14.8$, and 11.1 cents per 1000 gal. of product water respectively. $A$ break down of these costs is given in Table 2. Typical analyses of the raw water supply for those three plants are given in Table 1. Also included in Table 1 is the analysis of Boise geothermal water taken from the east penitentiary well on May 16, 1980.

The costs of chemicals for each of the three defluoridation facilities are shown in Table 3, where the fluoride and alkalinity of the water being treated, and the Boise geothermal water are also shown for comparison. Although the defluoridation plants are in the same geographic area, no direct relationship between the amount of fluoride or fluoride plus alkalinity and cost for chemicals is evident. In fact, one would expect the cost of chemicals at Vail to be higher than those at Desert Center based on total fluoride plus alkalinity. The difference could be due to efficiency of pretreatment and regeneration practices. It is evident that defluoridation facilities must be optimized for the quality and quantity of water being treated. 
Table 2. Operating costs, cents per 1000 gal., during 1978 for three alumina water defluoridation plants. (after Rubel and Woosley).

\begin{tabular}{|l|c|c|c|}
\hline \multirow{2}{*}{ Item } & \multicolumn{2}{|c|}{ LOCATION } \\
\cline { 2 - 4 } & $\begin{array}{l}\text { Desert Center, } \\
\text { California }\end{array}$ & $\begin{array}{l}\text { Vail, } \\
\text { Arizona }\end{array}$ & $\begin{array}{l}\text { Gila Bend, } \\
\text { Arizona }\end{array}$ \\
\hline Chemicals & 8.3 & 5.1 & 3.7 \\
Labor & 5.0 & 4.1 & 6.0 \\
Electricity & 0.5 & 0.4 & 0.6 \\
Alumina & 0.7 & Not reported & Not reported \\
Replacement & 0.3 & 0.8 & 0.8 \\
Misc. Costs & 14.8 & 10.4 & 11.1 \\
TOTAL & & & \\
\hline
\end{tabular}

Table 3. Alkalinity and fluoride content of water at three defluoridation plants and Boise geothermal well water and costs for chemicals at the three plants.

\begin{tabular}{|c|c|c|c|c|c|c|}
\hline LOCATION & $\mathrm{ppm}$ & $\begin{array}{l}\text { LINITY } \\
\mathrm{Eq} / 1000 \text { gal }\end{array}$ & $\mathrm{ppm}$ & $\begin{array}{l}\text { UOR IDE } \\
\text { Eq/1000 gal }\end{array}$ & $\begin{array}{l}A L K+F \\
E q / 1000 \text { gal }\end{array}$ & $\begin{array}{l}\text { Cost of } \\
\text { Chemicals/ } \\
1000 \text { gal }\end{array}$ \\
\hline Gila Bend & 30 & 2.27 & 6.0 & 1.19 & 3.47 & $3.7 \phi$ \\
\hline Desert Center & 77 & 5.83 & 7.5 & 1.49 & 7.32 & $8.3 \phi$ \\
\hline Vail & 171 & 12.95 & 4.5 & 0.90 & 13.85 & $5.1 \phi$ \\
\hline Boise & 120 & 9.08 & 18.4 & 3.66 & 12.74 & \\
\hline
\end{tabular}




\section{CONCLUSIONS}

1. It is technically feasible to reduce the fluoride content of the Boise geothermal water to an acceptable level by reverse osmosis, electrodialysis, or ion-exchange processes. All three methods leave a residue of concentrated fluorides which must still be disposed of in an environmentally acceptable manner.

2. Based on rough estimates of capital and operating costs, reverse osmosis and electrodialys is would cost about twice as much as ion exchange for defluoridation of geothermal water. ${ }^{24,25}$ A comparison of estimated costs is given in Table 4.

Table 4. Comparison of estimated capital and operating costs for RO, ED, and IX water treatment facilities, adjusted to 1979 dollars.

\begin{tabular}{|c|l|l|l}
\hline \multirow{2}{*}{ Item } & \multicolumn{3}{|c|}{ PROCESS } \\
\cline { 2 - 4 } & $\begin{array}{l}\text { Reverse } \\
\text { 0smosis }\end{array}$ & $\begin{array}{l}\text { Electro- } \\
\text { Dialys }\end{array}$ & $\begin{array}{l}\text { Ion Exchange } \\
\text { Alumina } \\
\text { Batch Regen. }\end{array}$ \\
\hline Capital costs per gpd capacity & $\$ 0.74-\$ 1.15$ & $\$ 0.82-\$ 0.90$ & $\$ 0.30-\$ 0.35$ \\
Operating costs per 1000 gal. & $\$ 0.55-\$ 0.70$ & $\$ 0.42-\$ 0.66$ & $\$ 0.12-\$ 0.20$ \\
\hline
\end{tabular}

* Based on data from Lynch and Mintz ${ }^{(25)}$.

${ }^{* *}$ Based on data from Rubel and Moosley ${ }^{(24)}$ for the Gila Bend plant.

3. Ion exchange processes for removing fluorides from water using alumina contact beds and batch regeneration procedures are we 11 defined, and economically feasible for treating public water supplies. 
4. Ion exchange processes using synthetic resins have never been devised solely for defluoridation of water, but are being used to improve the quality of water containing diverse substances. Several large scale continuous media regeneration plants using cation and anion exchangers are in operation.

5. Continuous exchanger regeneration appears to have several advantages over batch regeneration including greater absorption efficiency of the media, less media required, more uniform product, and more efficient use of regeneration chemicals.

6. Activated alumina preferentially absorbs fluoride and bicarbonate ions in the range of $\mathrm{pH} 5$ to 10 . The fluoride capacity increases with decreasing $\mathrm{pH}$ in this range because carbonates are converted to bicarbonates and then the carbonic acid, as acid is added to the water.

7. Pretreatment of Boise geothermal water with sulfuric acid to prevent absorption of $\mathrm{HCO}_{3}^{-}$on the alumina not only increases the efficiency of alumina for absorption of fluoride but also is preferred from an economic viewpoint. If bicarbonates were absorbed, sodium hydroxide, a . more expensive reagent than sulfuric acid, would be required to regenerate the alumina exchange medium.

8. A liquid waste, containing fluorides and other species from the separation process must be disposed. The waste volume from ion exchange processes is typically four to five percent of the total flow. One of the precipitation methods could be used to reduce the fluorides to a solid suitable for landfill disposal.

9. All of the possible uses and ways of disposing of the spent geothermal water should be considered before designing any defluoridation facility. These include blending with the Boise City water supply to yield a beneficial concentration of fluorides; blending with the Boise sewage plant stream during sewage treatment or at the effluent; and discharging as much as is environmentally acceptable into the Boise River.

10. Bench scale and pilot plant studies are needed before any accurate cost estimates can be made or plant design undertaken. 


\section{DEFLUORIDATE BY ION-EXCHANGE PROCESS}

A modest research effort using water from the geothermal production wells is needed to determine the best ion exchange medium and operating conditions. The following studies are recommended:

- Comparisons of alumina and candidate synthetic anion exchange resins for fluoride capacity as a function of $\mathrm{pH}$, temperature, and alkalinity.

- Comparisons of media absorption and regeneration efficiencies, costs, and interference due to other ionic species.

- Comparisons of batch and continuous media regeneration efficiencies and costs.

- Evaluations of the costs and benefits of $\mathrm{pH}$ control in the exchange process and in the effluent water.

- Determination of plant design criteria with respect to volumes of water to be processed and the levels of fluoride to be removed, operating modes, chemical storage and handling facilities, and emergency procedures. 
1. Boise Geothermal Energy Systems Plan, City of Boise, Energy Office, 150 N. Capitol, Boise, Idaho 83702, Jan. 1979.

2. Mink, Leland L. and Graham, David L., "Geothermal Potential of the West Boise Area," TREE-1162 October 1977 by EG\&G Idaho, Inc. under the U. S. Department of Energy Contract EY-76-C-07-1570.

3. National Interim Primary Drinking Water Regulations, EPA, Wtr. Prog. Fed. Reg. 40:248 (December 24, 1975).

4. Culp, Russe11 L., Wisner, George Mack, and Culp, Gordon L., "Handbook of Advanced Waste Water Treatment", Second Edition. Van Nostrand Reinhold Co. 1978.

5. Shields, C. P., "Reverse Osmosis for Municipal Water Supply," Water and Sewage Works 119, 64-70 Jan. 1972.

6. Sorg, Thomas J., "Treatment Technology to Meet the Interim Primary Drinking Water Regulations for Inorganics," J. AWWA 70 (2), 105, Feb. 1978.

7. Hornberg, C. D., Morin, O. J., and Hart, G. K., "Commercial Membrane Desalting Plants Performance and Cost Experience," J. National Water Supply Improvement Association January 1976, pp 1-9.

8. Moore, D. H., Greenfield, Iowa, Reverse Osmosis Desalting Plant, J. AWWA 64781 Nov. 1972.

9. Scheffer, S. L., "History of Desalting Operations, Maintenance, and Cost Experience at Buckeye, Arizona," J. AWWA 64, 726, Nov. 1972.

10. Culp, Russe11 L. and Stoltenberg, Howard A, "Fluoride Reduction at La Crosse, Kan.," J. AWWA 50427 March 1958.

11. Clarke, Ann N. and Wilson, David J., "The Absorbing Colloid Flotation of Fluoride Ion by Aluminum Hydroxide in Aqueous Media," Sep. Sci. 10417 (1975).

12. Scott, R. D., et al., "Fluoride in Ohio Water Supplies-Its Effects Occurence and Reduction," J. AWWA 29, 9, (1937).

13. Andco Fluoride Removal System, Andco Environmental Processes, Inc., 2005 Walden Avenue, P. 0. Box 988, Buffalo, New York 14240.

14. Harmon, J. A. and Kalichman, S. G., "Defluoridation of Drinking Water in Southern California," J. AWWA $\underline{57}, 245$, Feb. 1965.

15. Maier, F. J., "Water Defluoridation at Brittan: End of an Era," Public Works 102, 70, June 1971 
16. Savinelli, E. A. and Black, A. P., "Defluoridation of Water with Activated Alumina," J. AWWA $\underline{50}, 33$ Jan. 1958.

17. Wu, Yeun C. and Nitya, Anan, "Water Defluoridation with Activated Alumina," J. Emerison Eng. Div. of the Amer. Soc. of Civ. Eng. 105 (EE2), 357 (1979).

18. Bishop, Paul B. and Sansoucy, George, "Fluoride Removal from Drinking Water by Fluoridized Activated Alumina Adsorption," J. AWWA $\underline{50}$, 554, Oct. 1978.

19. Pilot Study of Fluoride and Arsenic Removal from Potable Water USEPA Contract 68-03-1351, Apri1 1979. Project Officer: Thomas J. Sorg by Rubel, Fredrick and Williams, Fred S.

20. Removal of Fluorides from Industrial Waste Water Using Activated Alumina USEPA Grant No. R-804377 1976, Project Officer: Mary K. Stinson by Frankel, Irwin and Juergens, Eric.

21. Alameda County Water District Fremont Water Softening Plant, Fremont, CA Private Communication with J. D. Newton and Wm. H. Blair.

22. Zabbon, W., Fithion, T, and Maneua 1, D. R., "Conversion of Coal-Mine Drainage to Potable water by Ion Exchange," J. AWWA Nov. 1972.

23. Maier, F. J., "Partial Defluoridation of Water," Public Works, 91 (11), 90 , Nov. 1960.

24. Rubel, Frederick and Woosley, R. D., "The Removal of Excess Fluoride from Drinking Water," J. AWWA 71, 45, Jan. 1979.

25. Lynch, M. A: and Mintz, Milton S., "Membrane and Ion-Exchange Processes A Review," J. AWWA 64 Nov. 1972. 
This report was prepared as an account of work sponsored by the United States Government. Neit her the United States nor the United Stites Department of Energy, nor any of their employees, nor any of their contractors, subcont ractors, or their employees, makes any warranty, express or implied, or assumes any legal liability or responsibility for the accuracy, completeness or usefulness of any infor mation, apparatus, product or process disclosed, or represents thit its use would not infringe privately owned rights.

Reference to a company or product name does not imply approval or recommendation of the product by the University of California or the U.S. Department of Energy to the exclusion of others that may be suitable.

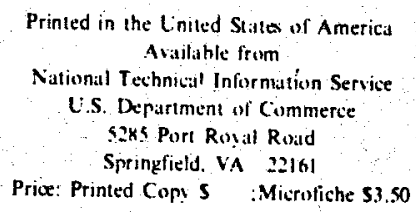

\begin{tabular}{cccc} 
Page Range & $\begin{array}{c}\text { Domestic } \\
\text { Price }\end{array}$ & $\begin{array}{c}\text { Page Range } \\
\text { S }\end{array}$ & $\begin{array}{c}\text { Domestic } \\
\text { Price }\end{array}$ \\
\hline $001-025$ & 5.00 & $326-250$ & $\$ 18.00$ \\
$026-050$ & 6.00 & $351-375$ & 19.00 \\
$051-075$ & 7.00 & $376-400$ & 20.00 \\
$076-100$ & 8.00 & $401-425$ & 21.00 \\
$101-125$ & 9.00 & $426-450$ & 22.00 \\
$126-150$ & 10.00 & $451-475$ & 23.00 \\
$151-175$ & 11.00 & $476-500$ & 24.00 \\
$176-200$ & 12.00 & $501-525$ & 25.00 \\
$201-225$ & 13.00 & $526-550$ & 26.00 \\
$226-250$ & 14.00 & $551-575$ & 27.00 \\
$251-275$ & 15.00 & $576-600$ & 28.00 \\
$276-300$ & 16.00 & $601-44$ & \\
$301-325$ & 17.00 & & \\
& & &
\end{tabular}

1 Add 2.00 for each additional 25 page herement from 601 pupes up. 